\title{
Ongoing studies of cell-based therapies for articular cartilage defects in Japan
}

\author{
This article was published in the following Dove Press journal: \\ Orthopedic Research and Reviews \\ 18 December 2014 \\ Number of times this article has been viewed
}

\author{
Takahiro Ogura' \\ Akihiro Tsuchiya ${ }^{2}$ \\ Shuichi Mizuno' \\ 'Department of Orthopedic Surgery, \\ Brigham and Women's Hospital and \\ Harvard Medical School, Boston, MA, \\ USA; ${ }^{2}$ Funabashi Orthopaedic Hospital \\ Sports Medicine Center, Funabashi, \\ Chiba, Japan
}

\begin{abstract}
Recently, cell-based therapies have generated great interest in the repair of articular cartilage defects and degeneration. Surgical treatments for these indications have multiple options, including marrow stimulation, osteochondral autograft transplant, and autologous chondrocyte implantation. The autologous chondrocyte implantation technique has been improved using a cell scaffold and other devices. Meanwhile, advanced cell-based therapies, including cultured stem cell treatment, have been studied in clinical trials. Most studies have been designed and authorized by institutional review boards and/or the regulatory agencies of the investigators' countries. For cellular products in regenerative medicine, regulations of many countries are amenable to expedited approval. This paper aims to provide an update on ongoing and prospective cell-based therapies, focusing on articular cartilage injury at designated institutions authorized by the Japanese Pharmaceutical and Medical Device Agency.
\end{abstract}

Keywords: autologous chondrocyte implantation, mesenchymal stem cell, knee joint

\section{Introduction}

The number of articular cartilage defects is greatly increasing, particularly in the young and middle-aged populations. When the defect is symptomatic, it causes joint disability followed by progressive osteoarthritis. ${ }^{1}$ Ultimate treatment results in total joint replacement, as articular cartilage has been recognized as being nonregenerative tissue in the orthopedic arena. ${ }^{2-5}$ Surgical treatments for cartilage defects include debridement, ${ }^{6}$ bone marrow stimulation, osteochondral autograft transplant (OAT), and autologous chondrocyte implantation (ACI, Figure 1). ACI in particular has attracted great interest as a cell-based therapy in younger populations. ACI aims to avoid total joint replacement and the associated limitations in prosthetic material durability. Using expanded populations of a patient's own cells, this technique has extended the treatment options and overcome some of the limitations of bone marrow stimulation and OAT. Moreover, the latest treatments have been developed using biomaterials or adult tissue-derived mesenchymal stem cells (MSCs). Although various cell therapies are in development elsewhere, we focus on new methods that are either in clinical trials or in clinical research, and approved by their own country's regulatory agency. In this review, we focus on the latest commercially available cell therapy and ongoing trials with cells conducted in Japan.

\section{Bone marrow stimulation and OAT}

The most popular treatments for cartilage defects are recognized to be bone marrow stimulation and OAT. Bone marrow stimulation includes drilling, ${ }^{7}$ abrasion, ${ }^{8}$ and 


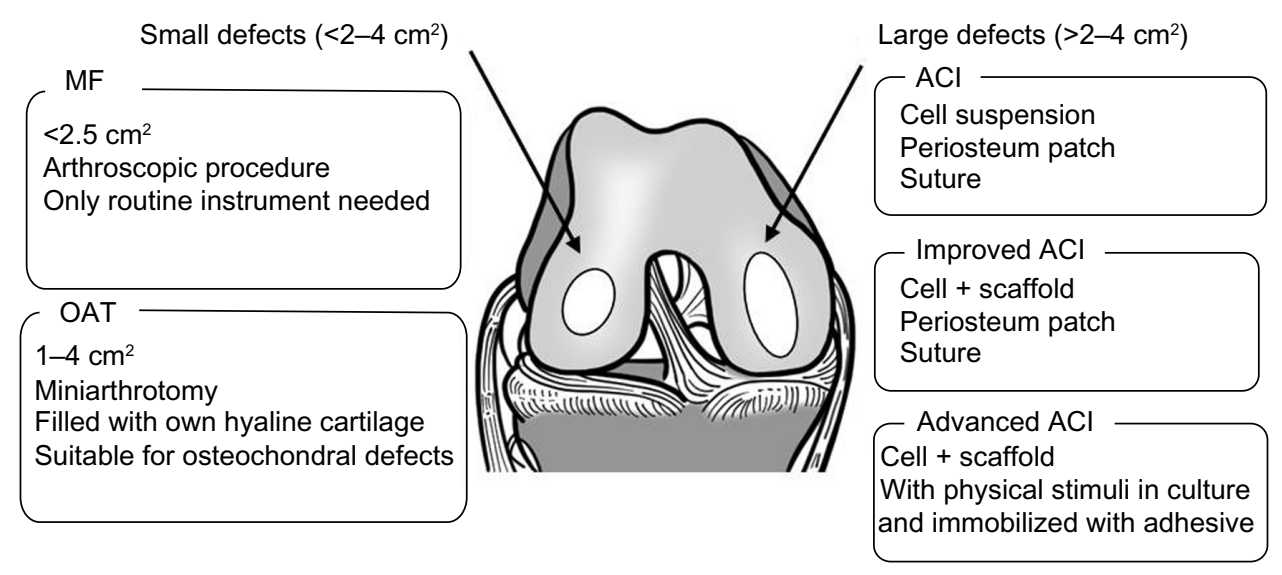

Figure I Treatment criteria, technical significance, and benefits.

Abbreviations: $\mathrm{ACl}$, autologous chondrocyte implantation; MF, microfracture; OAT, osteochondral autograft transplant.

microfracture. ${ }^{9}$ The indication for this treatment is generally a lesion area of less than $2.5 \mathrm{~cm}^{2}$. As this technique can be conducted minimally invasively and with routine surgical instruments, it is widely used for cartilage defects. This technique involves penetration into the subchondral bone to release bone marrow elements, including stem cells and growth factors, which form a clot and stimulate cartilage repair. ${ }^{10}$ However, histologic follow-up studies of microfracture indicated that cartilage defects were filled with fibrous tissue between 1 and 2 years post surgery. ${ }^{11,12}$ Moreover, the regenerated tissue was biomechanically suboptimal and eventually failed. ${ }^{13}$ In randomized studies of microfracture, the early revision rate was $2.5 \%$ before 2 years, $23 \%$ at year 2 , and $31 \%$ thereafter by year $5 .{ }^{14}$

Another intervention is OAT, or so-called "mosaicplasty". The indication for this treatment is generally a lesion area within approximately $2-4 \mathrm{~cm}^{2}$. This technique involves harvesting autologous osteochondral plugs from the femoral condyle and/or trochlea and transplanting them into the cartilage defect. Ultimately, the defect is filled with pieces of harvested hyaline cartilage and the underlying subchondral bone. ${ }^{15}$ However, OAT has concerns regarding donor tissue morbidity, unmatched shape of the host and donor cartilage surfaces, and a limitation of defect size. Randomized studies for the same indication regarding the superiority of OAT compared with microfracture have been somewhat controversial. Patients treated with OAT had significantly better clinical outcomes according to the International Cartilage Repair Society (ICRS) score 10 years postoperatively than microfracture $(P<0.001) .{ }^{16}$ In addition, OAT maintained a significantly higher activity level according to Marx Activity Rating Scale scores than microfracture by 5 years $(P=0.02) .{ }^{17}$ On the other hand, a follow-up study with a median of
9.8 years indicated no significant difference between OAT and microfracture based on Lysholm scores, Knee Injury and Osteoarthritis Outcome Score (KOOS), muscle strength, and radiographic outcome. ${ }^{18}$ Therefore, microfracture and OAT still require more information for appropriate indications and outcomes.

\section{$\mathrm{ACl}$}

ACI was developed in the early 1990s to treat focal defects in the knee joint. ${ }^{19}$ Since then, over 15,000 ACI procedures have been performed in the USA, and over 20,000 had been performed in Europe by 2010. ${ }^{20}$ Briefly, ACI requires two surgeries. First, cartilage fragments are harvested from the nonweight-bearing site in the patellofemoral condyle. The fragments are enzymatically digested for isolation of chondrocytes followed by cell number expansion in monolayer culture. At the second surgery several weeks after cartilage harvest, a suspension of the chondrocytes is injected into the defect, and covered with the harvested periosteum flap from the tibia of the same leg.

Proof of concept of ACI was demonstrated using a rabbit model prior to clinical study. ${ }^{21}$ In this animal model, synovitis and osteophyte formation are markedly decreased in the joint treated with ACI compared to the nontreated joint. In addition, the articular cartilage surface was smooth and glistening white, similar to normal hyaline cartilage. Histologically, the defect was filled with a cartilage matrix that was similar to adjacent tissue at 6 weeks following cell implantation. After achieving successful results in a rabbit model, Brittberg et al addressed the usefulness of ACI clinically and histologically. ${ }^{19}$ At an average of 2 years post ACI, 14 of 16 patients showed good to excellent clinical outcomes and histologic appearance of hyaline cartilage. Recently, the extended 
follow-up study indicated significant improvement in joint function, reduction of symptoms, and regeneration of hyalinelike cartilage. ${ }^{22}$ Arthroscopic findings were normal or nearly normal in $87.7 \%-93 \%$ according to the ICRS scale. ${ }^{23}$ In addition, the other study conducted by Minas et al showed that at a minimum of 10 years post ACI, there was a survivorship of ACI grafts in $71 \%$ and improved function in $75 \%$ of patients with symptomatic cartilage defects. ${ }^{24}$

Although ACI has become popular, several concerns have been raised. ACI requires two surgeries, resulting in inconvenience to the patient, a longer period of rehabilitation, and higher cost. Harvesting a periosteum flap is also a rather painful intervention ${ }^{25}$ and the regenerating cartilage increases the risks of hypertrophy, ${ }^{26,27}$ catching, and swelling. ${ }^{28,29}$ Moreover, expansion of chondrocytes in monolayer culture risks losing the chondrocytic phenotypes. From a technical standpoint, the injected cell suspension has risks of leaking out from the pocket after resuming normal joint-loading, as well as moving around within the pocket. ${ }^{28,30,31}$ Therefore, these concerns motivated the development of improved ACI using a cell scaffold and medium supplements.

\section{Improved ACl}

Cell scaffolds are being widely developed elsewhere using extracellular matrix extracted from animals, then synthesized with biodegradable polymers for constructing a scaffold with chondrocytes. A hyaluronan-based scaffold would also improve maintenance of chondrocyte phenotypes. ${ }^{32}$ In Japan, atelocollagen gel (acid-soluble, pepsin-digested collagen) has been widely used for three-dimensional cell culture. Proof of concept of this improved ACI using the atelocollagen gel scaffold revealed that the histologic quality of regenerative tissue was significantly higher than using classic ACI, and higher than the periosteum flap and no treatment control in rabbits. ${ }^{33-36}$ Moreover, human articular chondrocytes in the gel efficiently promoted the production of cartilage-specific matrices and avoided an increase of predominantly collagen type I in vitro. ${ }^{34}$ A leading clinical study of the improved ACI using this gel construct was conducted by Ochi et al. ${ }^{37}$ They reported that the clinical outcome by Lysholm score was significantly improved at 2 years after implantation $(P<0.001)$. Most recently, the improved ACI showed a good Lysholm score at a mean 8 years (range 5.0-11.3 years), and a significant correlation between arthroscopic ICRS grade at 2 years and final Lysholm scores $(P<0.01)$. Histologically, hyaline-like cartilage was seen (ICRS-2 histologic scale $70.4 \pm 20.8, n=40$ ), although a normal layered structure was not seen at 1 year after implantation.
In addition, other improvements have been made for manufacturing improved ACI. Tohyama et al changed the serum source from patient serum $15 \%$ to fetal bovine serum (FBS) $10 \%$, as chondrocytes with $10 \%$ FBS proliferated six times faster than those with patient serum. They also changed the starting time of enzymatic chondrocyte isolation from 2 hours to 1 day after harvest (Table 1). ${ }^{30,38}$ Although the manufacturing processes were changed for practical reasons, clinical evaluations using those methods have not yet been completed. If the methods do not cause any significant changes, those culture protocols will be useful for consistent and convenient processes.

Regarding complications, the overall incidence was $11 \%-30 \%$ in these studies and hypertrophy of the transplant was most common. Neimeyer reported that the incidence of hypertrophy by periosteum-covered ACI was $15.4 \% .{ }^{27}$ Using a periosteum patch is still problematic in improved ACI and further development of stabilizing the transplant without a periosteum flap is required to reduce these complications.

\section{Advanced ACI for cartilage defects}

Beyond improvement of ACI, various methods of ACI have been developed using biological, chemical, and physical methods. Conceptually, these methods are used by mimicking physiologic changes in chondrocytes. Mizuno et al have developed a novel cell culture method with hydrostatic pressure for promoting chondrogenesis by autologous chondrocytes. ${ }^{39,40}$ The rationale for using hydrostatic pressure, which is a passively loaded stress on articular cartilage similar to joint-loading and weight-bearing, was that hydrostatic pressure-loaded chondrocytes produced and accumulated more cartilage extracellular matrix within a collagen gel/ sponge scaffold. ${ }^{41,42}$ Moreover, the cell gel/sponge construct, Neocart $^{\circledR}$, was implanted into the cartilage defect using a novel collagen/polyethylene glycol-based glue. The clinical results of Neocart (ie, International Knee Documentation Committee score, KOOS, visual analog scale scores) were significantly superior compared with microfracture 2 years after implantation $(P<0.05) .{ }^{43}$ An advantage of using hydrostatic pressure is that physical stimuli on chondrogenesis needs less safety concern than biological and chemical stimuli. Globally, other improved ACIs have been developing and are voluntarily registered at ClinicalTrials. gov, supported by the US National Institutes of Health. From these lists, two cell-based therapies should be known based on their level of clinical study and support by scientific reports. Matrix-associated cartilage implantation $\left(\mathrm{MACI}^{\circledR}\right.$ ) has been developed using type I/III bilayer collagen membranes. ${ }^{44,45}$ Autologous chondrocytes 


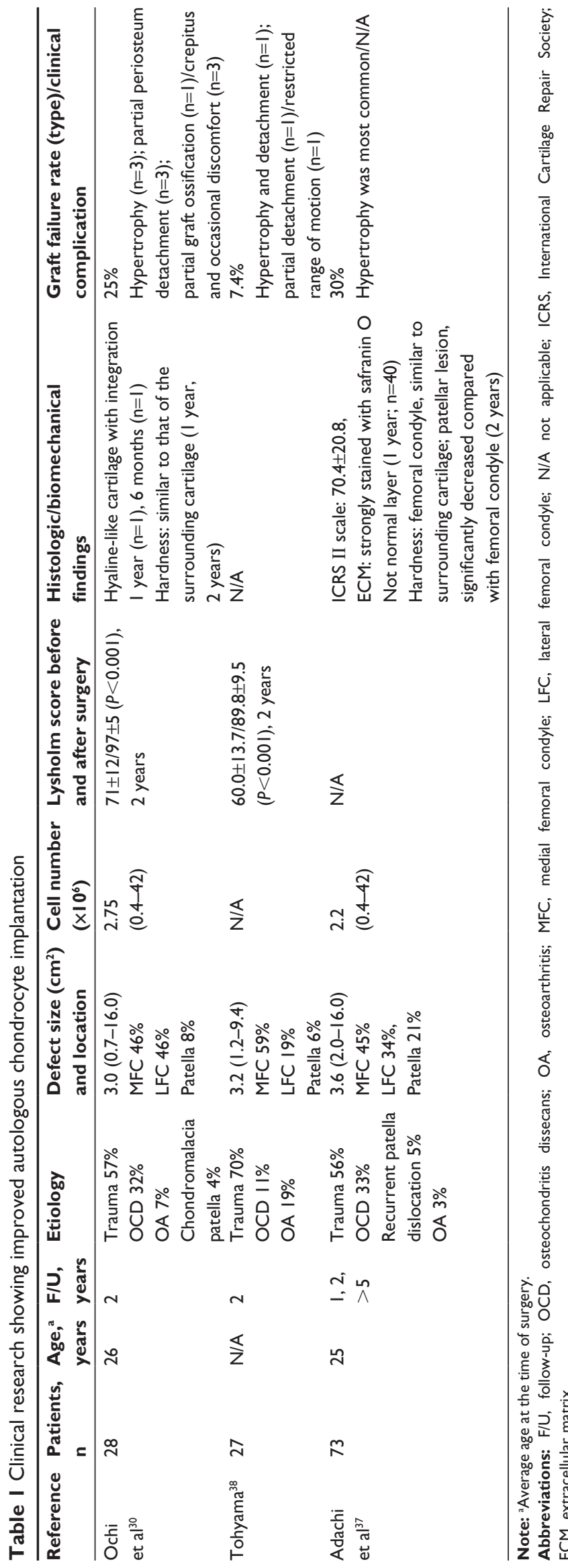

expanded in number were seeded onto the membrane, incubated, and implanted into the cartilage lesion. This method allowed implantation without a periosteum flap and reduced hypertrophy of the graft. This membrane alone was also utilized for improving the ACI instead of a periosteum flap, and showed a similar reduction of hypertrophy. These clinical studies strongly suggest that refraining from the use of periosteum could be one strategy for preventing adverse events. Another therapy was that particulate juvenile articular cartilage (DeNovo $\mathrm{NT}^{\circledR}$ ) harvested from allogeneic juvenile cadaveric cartilage was implanted into lesions with fibrin glue. ${ }^{46}$ In addition, allogeneic engineered chondrocyte implantation (DeNovo $\mathrm{ET}^{\circledR}$ ) is undergoing clinical trials. ${ }^{47}$ These methods are advantageous when compared with ACI, as both implant techniques do not require two surgeries. If a smaller number of donors are sufficient, using allogeneic cartilage can be useful. Clinical outcomes are still incomplete, as the dataset is not enough to provide statistical power yet. This technique still needs more time and information before routine implementation of ACI.

Overall, methodologies for cell-based therapy have been improved for in vitro cell culture and implantation techniques. Clinical outcomes following improved and advanced ACIs are adding up long-term. However, the only way to obtain histologic data is from failure cases that undergo total joint replacement. Improved and advanced ACI will continue to provide functional recovery and impact other treatment strategies in regenerative medicine. Meanwhile, some metaanalyses were conducted between ACI and bone marrow stimulation and between ACI and OAT. ${ }^{48,49}$ These analyses showed no significant difference between treatments. Although they were performed by matching demographic background and lesion size, each study was designed with other varied indications (eg, lesion location, lesion number, preoperative duration of symptoms, previous treatment, and desired physical activity). Thus, other indications have a chance to influence interpretation of these analyses. Concerning indications, well-designed and long-term follow-up studies will provide more comparable data sets for clinical guidelines.

\section{MSC-based therapy}

Recently, MSCs have attracted much interest in the field of tissue regeneration because of their relative ease of isolation and their amenability to ex vivo expansion while retaining the potential to differentiate into a variety of connective tissues, including bone, cartilage, tendon, muscle, and adipose tissue..$^{50-52}$ MSCs have been identified and isolated from bone marrow, ${ }^{53-55}$ synovial membrane, ${ }^{56}$ periosteum, ${ }^{57}$ 
skeletal muscle,${ }^{58}$ adipose tissue,${ }^{59}$ trabecular bone, ${ }^{60}$ and umbilical cord blood cells. ${ }^{61}$ Bone marrow-derived MSCs and synovium-derived MSCs (S-MSCs) have been used for cartilage regeneration, particularly in Japan (Table 2). ${ }^{62-65}$

\section{Bone marrow-derived MSCs}

It has been reported that MSCs from human bone marrow are capable of chondrogenesis, osteogenesis, and adipogenesis in vitro. $^{52,55}$ Using a rabbit injury model, Wakitani et al transplanted autologous bone marrow-derived MSCs embedded in collagen gel into an osteochondral defect $(3 \times 6 \mathrm{~mm}, 3 \mathrm{~mm}$ in depth) in medial femoral condyles, and cover the defects with a periosteum flap. The defect was mostly replaced with hyaline cartilage at 2 weeks after transplantation, and was followed by subchondral bone formation at 4 weeks. Ultimately, the defect was completely repaired by 24 weeks. ${ }^{66}$ After proof of concept using rabbits, these investigators performed bone marrow-derived MSC transplants in three indications: traumatic cartilage defects in the patella alone, the patellofemoral joint, and osteoarthritic lesions in the medial femoral condyle. Bone marrow-derived MSCs were harvested from the anterior iliac crest, expanded for 3 weeks, and embedded in collagen gel. This construct was then transplanted with periosteum. In the traumatic defect cases, clinical symptoms were improved significantly by 8 months and the defects were filled histologically with fibrocartilage by 1 year. ${ }^{62,63}$ In the osteoarthritis cases, they compared the bone marrow-derived MSC construct (cells within a scaffold) and the scaffold alone in 24 patients who were concomitantly treated with high tibial osteotomy. ${ }^{64}$ By a mean follow-up of 16 months, the clinical outcome was not different between the bone marrow-derived MSC construct and the scaffold alone using the Hospital for Special Surgery knee rating scale. Moreover, the longer follow-up of 64 months also indicated the same trend ${ }^{67}$ However, arthroscopic and histologic evaluations were significantly better in the bone marrow-derived MSC construct than in the scaffold alone, with appearance of fibrocartilage in almost all areas of the repair $(P<0.05){ }^{66,68}$ Overall, bone marrow-derived MSC/collagen gel transplantation can be clinically effective and is one of the options for traumatic defects. However, well-designed studies are still needed to draw conclusions regarding effectiveness, because both the existing reports are case studies with no controls.

\section{Synovium membrane-derived MSCs}

The rationale for using S-MSCs comes from the idea that S-MSCs represent a more natural strategy to promote spontaneous healing of articular cartilage in the joint space.

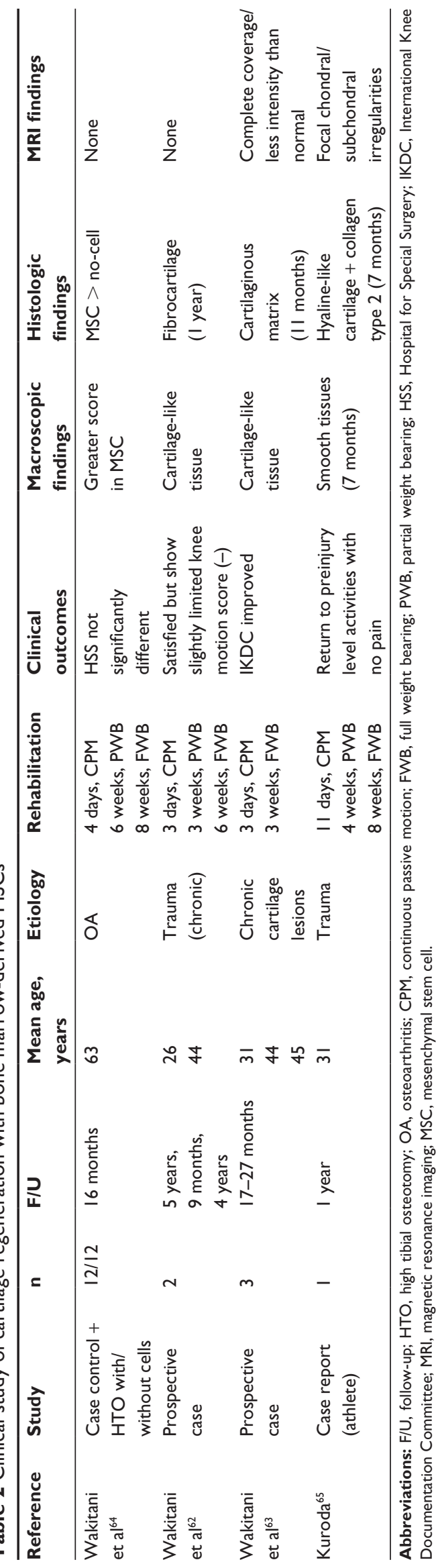


Sekiya et al reported that chondrogenesis of S-MSCs from humans and various animals was superior to, or at least comparable with, bone marrow-derived MSCs with regard to the gene expression profile in vitro, ${ }^{69}$ and superior to MSCs from periosteum, adipose tissue, and muscle with regard to proliferation and chondrogenesis in vitro. ${ }^{70-72}$ An animal study showed that S-MSCs and bone marrow-derived MSCs had greater chondrogenic potential histologically ${ }^{66}$ than MSCs from adipose tissue and skeletal muscle in the rabbit. ${ }^{73}$ In addition, delivery methods for MSCs were also explored because the regeneration processes (resurfacing) would be different from ACI. Placing a suspension of S-MSCs in the cartilage defect for 10 minutes resulted in more than $60 \%$ of S-MSCs adhering within the defect, and promotion of cartilage regeneration ex vivo in human and rabbit cartilage. ${ }^{74}$

Based on the ex vivo study by Koga et al, S-MSC transplantation was approved for clinical study in the treatment of articular cartilage defects. ${ }^{75}$ Briefly, S-MSCs were harvested arthroscopically, expanded for 2 weeks, and suspended in phosphate-buffered saline. Then, the S-MSCs suspension was implanted to the defect arthroscopically. They reported regeneration of cartilage, reduction in defect size, and symptomatic improvement in most patients for 3 years. Further investigation is needed to evaluate the effectiveness of S-MSC transplantation.

\section{Cell processing and innovative technologies}

Conceptually, cell-based cartilage regeneration has been conducted by implanting autologous chondrocytes, chondroinduced stem cells, or nontreated stem cells. To make treatment more convenient and reliable, isolation of cells from patients and their expansion are critical processes in vitro. Minimizing passage numbers is necessary to avoid the risk of declining their phenotypes. However, a certain number of chondrocytes is necessary to fill a cell construct with newly synthesized cartilage matrix. Using a three-dimensional scaffold has the advantage of maintaining chondrocytic phenotypes while implanting a cell construct securely. ${ }^{30,40,44-46}$

Without inducing MSCs to chondrocytes, MSCs were implanted into a defect. A higher cell density of MSCs in the defect appears to be necessary for cartilage regeneration and differentiation into chondrocytes in situ without a cell construct and differentiation factors, eg, transforming growth factor- $\beta .^{75-79}$ Koga et al embedded MSCs in collagen gel and incubated the cell/gel construct in medium including FBS, bone morphogenetic protein, transforming growth factor- $\beta$, dexamethasone, ascorbate-2-phosphate, pyruvate, proline, and insulin, transferrin, and selenious acid to differentiate into chondrocytes in vitro. Next, $5 \times 10^{7}$ chondro-induced $\mathrm{MSC} / \mathrm{mL}$ successfully promoted cartilage regeneration in the rabbit, but a concentration of $1 \times 10^{6}$ cells $/ \mathrm{mL}$ failed. ${ }^{73}$ The relevance of these two distinct culture processes using MSCs is unclear in the clinical setting.

An appropriate serum source was a concern due to not only the quality of the serum components, but also because of potential immune rejection of the xenograft. Autologous chondrocyte culture could switch from patient serum to FBS due to consistent quality and higher proliferation rate. However, serum for MSC culture is still under consideration. Motility and growth of bone marrow-derived MSCs were higher in autologous serum than in FBS. ${ }^{80,81}$ Human S-MSCs with autologous serum had a higher proliferation rate than those with FBS; however bone marrow-derived MSCs with FBS had a higher proliferation rate than those with autologous serum. ${ }^{82}$ Moreover, the chondrogenic potential of bone marrow-derived MSCs and S-MSCs with human serum was lower than that with FBS. These various studies suggest that the serum source should be chosen depending on the cell proliferation and differentiation of MSCs.

\section{Prospective treatments and evaluation for cartilage injury}

In this update on the latest cell-based therapies conducted in Japan, we focus on various treatment options for articular cartilage injury. None of the new treatments reported direct adverse events in registered clinical research. In particular, it was proven that autologous chondrocytes and adult tissue-derived stem cells are safe after implantation. Prior to cell implantation, cellular characteristics can be determined regardless of the cell source and cell culture method. However, the fate of the implanted cells is still unclear. Although an animal study partially reproduces the regenerative process of articular cartilage in vivo, we must recognize that the long-term failure cases were not available from these animal studies. The behavior of stem cells in animals is different from that in humans. Therefore, in order to establish reliable regenerative treatments, it is necessary to gain more information about the mechanisms of resurfacing cartilage defects. Due to the inherent limitations of tracking and imaging implanted cells, clinical symptoms, such as joint pain and decreased range of motion (using the ICRS, KOOS, Lysholm grading systems) are the only way to compare cell-based therapies. Thus, clinical evaluation requires extended study durations, resulting in the slow development of new treatments. The development of an efficient evaluation system 


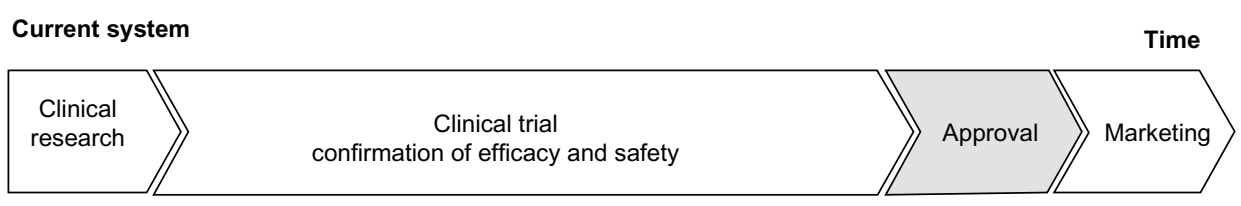

New system after October 2014

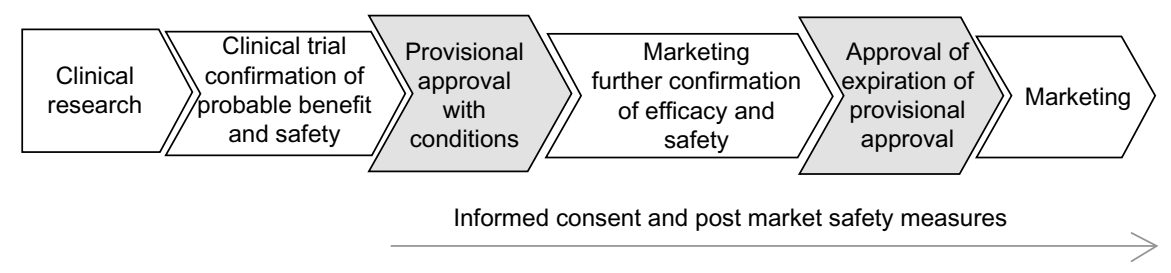

Figure $2 \mathrm{New}$ approval system for commercialization of cell therapy products.

would therefore take on a role equally important to that of successful cell therapy.

All clinical research on cell-based therapy in Japan has been carried out using single-arm studies due to ethical issues. However, microfracture has been used as a control arm for test treatment in the USA because microfracture and OAT are conducted for indications similar to ACI. Moreover, some ACI, stem cell implantation, and OAT procedures were conducted with high tibial osteotomy in order to reduce stress at the injured site by changing the weight-bearing alignment of the knee joint. Although this is beneficial for patients, an evaluation of outcomes is rather complex. Thus, data from each study are less interchangeable. If a database of the same or similar indications for microfracture and OAT is established, it will be of great benefit for developing future cell-based therapies. A nationwide joint registry for indications and treatments in Japan will be helpful for collecting comprehensive relevant data about cell-based therapy in order to provide an early warning of issues relating to patient safety. In fact, this type of joint registry for artificial joint implantation was previously organized for the continuous improvement of outcome quality and ensuring the quality and cost-effectiveness of joint replacement surgery.

New Japanese regulations for clinical research and trials will be implemented in November 2014 (Figure 2) ${ }^{83}$ The concept of the new regulations will be to bring new treatments to patients as rapidly as possible. Under the previous regulatory system, the approval process was long and tedious. However, under the upcoming regulations, provisional approval will be made for commercialization if probable benefit and safety are confirmed, although certain conditions may apply. Early provisional approval will greatly benefit patients, although patients will be required to cover the full or partial cost of treatment. It could, however, cover tissues with difficult regeneration, including cases with a potential threat to life and loss of tissue/organ function, for which there are currently no available treatments. Regenerative medicine includes cure of life-threatening disease, functional recovery of damaged tissues, and reconstruction of tissue shapes. Being able to evaluate study designs and outcomes with an internationally recognized system would greatly aid the research process.

\section{Acknowledgment}

TO has received a training fellowship from Funabashi Orthopaedic Hospital (Chiba, Japan). The authors thank Mr Chris Vercollone and Ms Yuki Mizuno for preparation of the manuscript.

\section{Disclosure}

The authors report no conflicts of interest in this work.

\section{References}

1. Heir S, Nerhus TK, Røtterud JH, et al. Focal cartilage defects in the knee impair quality of life as much as severe osteoarthritis: a comparison of knee injury and osteoarthritis outcome score in 4 patient categories scheduled for knee surgery. Am J Sports Med. 2010;38(2): 231-237.

2. Newman AP. Articular cartilage repair. Am J Sports Med. 1998;26(2): 309-324.

3. Mandelbaum BR, Browne JE, Fu F, et al. Articular cartilage lesions of the knee. Am J Sports Med. 1998;26(6):853-861.

4. Mankin HJ. The response of articular cartilage to mechanical injury. J Bone Joint Surg Am. 1982;64(3):460-466.

5. Buckwalter JA, Mankin HJ. Articular cartilage: tissue design and chondrocyte-matrix interactions. Instr Course Lect. 1998;47:477-486.

6. Hubbard MJ. Articular debridement versus washout for degeneration of the medical femoral condyle. A five-year study. J Bone Joint Surg Br. 1996;78(2):217-219.

7. Pridie KH. A method of resurfacing osteoarthritic knee joints. J Bone Joint Surg Br. 1959;41:618-619.

8. Johnson LL. Arthroscopic abrasion arthroplasty historical and pathologic perspective: present status. Arthroscopy. 1986;2(1):54-69. 
9. Steadman JR, Briggs KK, Rodrigo JJ, et al. Outcomes of microfracture for traumatic chondral defects of the knee: average 11-year follow-up. Arthroscopy. 2003;19(2):477-484.

10. Steadman JR, Rodkey WG, Rodrigo JJ. Microfracture: surgical technique and rehabilitation to treat chondral defects. Clin Orthop Relat Res. 2001;391 Suppl:S362-S369.

11. Horas U, Pelinkovic D, Herr G Aigner T, Schnettler R. Autologous chondrocyte implantation and osteochondral cylinder transplantation in cartilage repair of the knee joint. A prospective, comparative trial. J Bone Joint Surg Am. 2003;85(2):185-192.

12. Tins BJ, McCall IW, Takahashi T, et al. Autologous chondrocyte implantation in knee joint: MR imaging and histologic features at 1-year follow-up. Radiology. 2005;234(2):501-508.

13. Batty L, Dance S, Bajaj S, Cole BJ. Autologous chondrocyte implantation: an overview of technique and outcomes. ANZ J Surg. 2011;81(1-2):18-25.

14. Mithoefer K, McAdams T, Williams RJ, Kreuz PC, Mandelbaum BR. Clinical efficacy of the microfracture technique for articular cartilage repair in the knee: an evidence-based systematic analysis. Am J Sports Med. 2009;37(10):2053-2063.

15. Bentley G, Biant LC, Carrington RW, et al. A prospective, randomised comparison of autologous chondrocyte implantation versus mosaicplasty for osteochondral defects in the knee. J Bone Joint Surg Br. 2003;85(2):223-230.

16. Gudas R, Gudaite A, Pocius A, et al. Ten-year follow-up of a prospective, randomized clinical study of mosaic osteochondral autologous transplantation versus microfracture for the treatment of osteochondral defects in the knee joint of athletes. Am J Sports Med. 2012;40(11): 2499-2508.

17. Krych AJ, Harnly HW, Rodeo SA, Williams RJ, 3rd. Activity levels are higher after osteochondral autograft transfer mosaicplasty than after microfracture for articular cartilage defects of the knee: a retrospective comparative study. J Bone Joint Surg. 2012;94(11):971-978.

18. Ulstein S, Arøen A, Røtterud JH, Løken S, Engebretsen L, Heir S. Microfracture technique versus osteochondral autologous transplantation mosaicplasty in patients with articular chondral lesions of the knee: a prospective randomized trial with long-term follow-up. Knee Surg Sports Traumatol Arthrosc. 2014;22(6):1207-1215.

19. Brittberg M, Lindahl A, Nilsson A, Ohlsson C, Isaksson O, Peterson L. Treatment of deep cartilage defects in the knee with autologous chondrocyte transplantation. N Engl J Med. 1994;331(14):889-895.

20. Minas T. A Primer in Cartilage Repair and Joint Preservation of the Knee: Expert Consult. Philadelphia, PA, USA: Elsevier Health Sciences; 2011.

21. Grande DA, Pitman MI, Peterson L Menche D, Klein M. The repair of experimentally produced defects in rabbit articular cartilage by autologous chondrocyte transplantation. J Orthop Res. 1989;7(2):208-218.

22. Brittberg M. Cell carriers as the next generation of cell therapy for cartilage repair: a review of the matrix-induced autologous chondrocyte implantation procedure. Am J Sports Med. 2010;38(6):1259-1271.

23. Brittberg M, Peterson L, Sjögren-Jansson E, Tallheden T, Lindahl A. Articular cartilage engineering with autologous chondrocyte transplantation. A review of recent developments. J Bone Joint Surg Am. 2003;85-A Suppl 3:109-115.

24. Minas T, Von Keudell A, Bryant T, Gomoll AH. The John Insall Award: a minimum 10-year outcome study of autologous chondrocyte implantation. Clin Orthop Relat Res. 2014;472(1):41-51.

25. Marcacci M, Zaffagnini S, Kon E, Visani A, Iacono F, Loreti I. Arthroscopic autologous chondrocyte transplantation: technical note. Knee Surg Sports Traumatol Arthrosc. 2002;10(3):154-159.

26. Brittberg M. Autologous chondrocyte transplantation. Clin Orthop Relat Res. 1999;367 Suppl:S147-S155.

27. Niemeyer P, Pestka JM, Kreuz PC, et al. Characteristic complications after autologous chondrocyte implantation for cartilage defects of the knee joint. Am J Sports Med. 2008;36(11):2091-2099.

28. Haddo O, Mahroof S, Higgs D, et al. The use of chondrogide membrane in autologous chondrocyte implantation. Knee. 2004;11(1):51-55.
29. Steinwachs M, Kreuz PC. Autologous chondrocyte implantation in chondral defects of the knee with a type I/III collagen membrane: a prospective study with a 3-year follow-up. Arthroscopy. 2007;23(4): 381-387.

30. Ochi M, Uchio Y, Kawasaki K, Wakitani S, Iwasa J. Transplantation of cartilage-like tissue made by tissue engineering in the treatment of cartilage defects of the knee. J Bone Joint Surg Br. 2002;84(4): 571-578.

31. Sohn DH, Lottman LM, Lum LY, et al. Effect of gravity on localization of chondrocytes implanted in cartilage defects. Clin Orthop Relat Res. 2002;394:254-262.

32. Grigolo B, Lisignoli G, Piacentini A, et al. Evidence for redifferentiation of human chondrocytes grown on a hyaluronan-based biomaterial (HYAff 11): molecular, immunohistochemical and ultrastructural analysis. Biomaterials. 2002;23(4):1187-1195.

33. Ochi M, Uchio Y, Matsusaki M, Wakitani S. Cartilage repair: a new surgical procedure of cultured chondrocyte transplantation. In: Chan KM, Fu F, Maffuli N, Rolf C, Kurosaka M, Liu S, editors. Controversies in Orthopedic Sport Medicine. Hong Kong: Williams \& Wilkins Asia-Pacific Ltd; 1998.

34. Uchio Y, Ochi M, Matsusaki M, Kurioka H, Katsube K. Human chondrocyte proliferation and matrix synthesis cultured in atelocollagen gel. J Biomed Mater Res. 2000;50(2):138-143.

35. Katsube K, Ochi M, Uchio Y, et al. Repair of articular cartilage defects with cultured chondrocytes in atelocollagen gel: comparison with cultured chondrocytes in suspension. Arch Orthop Trauma Surg. 2000;120(3-4):121-127.

36. Wakitani S, Kimura T, Hirooka A, et al. Repair of rabbit articular surfaces with allograft chondrocytes embedded in collagen gel. $J$ Bone Joint Surg Br. 1989;71(1):74-80.

37. Adachi N, Ochi M, Deie M, et al. Implantation of tissue-engineered cartilage-like tissue for the treatment for full-thickness cartilage defects of the knee. Knee Surg Sports Traumatol Arthrosc. 2014;22(6): 1241-1248.

38. Tohyama H, Yasuda K, Minami A, et al. Atelocollagen-associated autologous chondrocyte implantation for the repair of chondral defects of the knee: a prospective multicenter clinical trial in Japan. J Orthop Sci. 2009;14(5):579-588.

39. Mizuno S, Ushida T, Tateishi T, Glowacki J. Effects of physical stimulation on chondrogenesis in vitro. Mat Sci Eng C. 1998;6: 301-306.

40. Mizuno S, Tateishi T, Ushida T, Glowacki J. Hydrostatic fluid pressure enhances matrix synthesis and accumulation by bovine chondrocytes in three-dimensional culture. J Cell Physiol. 2002;193(3):319-327.

41. Blahut EB, Kusanagi A, Mascarenhas AC, Johnson J, Berlowitz-Tarrant LJ, Mizuno S. Effects of medium flow rate on extracellular matrix accumulation by swine articular chondrocytes in collagen sponges. In: Transactions of the 49th Annual Orthopaedic Research Society Meeting. Rosemont, IL, USA: Orthopaedic Research Society; 2003.

42. Mascarenhas AC, Kusanagi A. Blahut EB, et al. Hydrostatic pressure stimulates extracellular matrix accumulation by swine articular chondrocytes in 3D collagen sponges. In: Transactions of the 49th Annual Orthopaedic Research Society Meeting. Rosemont, IL, USA: Orthopaedic Research Society; 2003.

43. Crawford DC, DeBerardino TM, Williams RJ 3rd. NeoCart, an autologous cartilage tissue implant, compared with microfracture for treatment of distal femoral cartilage lesions: an FDA phase-II prospective, randomized clinical trial after two years. J Bone Joint Surg Am. 2012;94(11):979-989.

44. Dunkin BS, Lattermann C. New and emerging techniques in cartilage repair: MACI. Oper Tech Sports Med. 2013;21(2):100-107.

45. Jacobi M, Villa V, Magnussen RA, Neyret P. MACI - a new era? Sports Med Arthrosc Rehabil Ther Technol. 2011;3(1):10.

46. Farr J, Tabet SK, Margerrison E, Cole BJ. Clinical, radiographic, and histological outcomes after cartilage repair with particulated juvenile articular cartilage: a 2-year prospective study. Am J Sports Med. 2014;42(6):1417-1425. 
47. Adkisson HD 4th, Martin JA, Amendola RL, et al. The potential of human allogeneic juvenile chondrocytes for restoration of articular cartilage. Am J Sports Med. 2010;38(7):1324-1333.

48. Negrin LL, Vécsei V. Do meta-analyses reveal time-dependent differences between the clinical outcomes achieved by microfracture and autologous chondrocyte implantation in the treatment of cartilage defects of the knee? J Orthop Sci. 2013;18(6):940-948.

49. Vasiliadis HS, Wasiak J. Autologous chondrocyte implantation for full thickness articular cartilage defects of the knee. Cochrane Database Syst Rev. 2010;10:CD003323.

50. Friedenstein AJ, Petrakova KV, Kurolesova AI, Frolova GP. Heterotopic of bone marrow. Analysis of precursor cells for osteogenic and hematopoietic tissues. Transplantation. 1968;6(2):230-247.

51. Ashton BA, Allen TD, Howlett CR, Eaglesom CC, Hattori A, Owen M. Formation of bone and cartilage by marrow stromal cells in diffusion chambers in vivo. Clin Orthop Relat Res. 1980;151:294-307.

52. Johnstone B, Hering TM, Caplan AI, Goldberg VM, Yoo JU. In vitro chondrogenesis of bone marrow-derived mesenchymal progenitor cells Exp Cell Res. 1998;238(1):265-272.

53. Friedenstein AJ, Chailakhyan RK, Latsinik NV, Panasyuk AF, Keiliss-Borok IV. Stromal cells responsible for transferring the microenvironment of the hemopoietic tissues. Cloning in vitro and retransplantation in vivo. Transplantation. 1974;17(4):331-340.

54. Prockop DJ. Marrow stromal cells as stem cells for nonhematopoietic tissues. Science. 1997;276(5309):71-74.

55. Pittenger MF, Mackay AM, Beck SC, et al. Multilineage potential of adult human mesenchymal stem cells. Science. 1999;284(5411):143-147.

56. De Bari C, Dell'Accio F, Tylzanowski P, Luyten FP. Multipotent mesenchymal stem cells from adult human synovial membrane. Arthritis Rheum. 2001;44(8):1928-1942.

57. Fukumoto T, Sperling JW, Sanyal A, et al. Combined effects of insulinlike growth factor- 1 and transforming growth factor-beta 1 on periosteal mesenchymal cells during chondrogenesis in vitro. Osteoarthritis Cartilage. 2003;11(1):55-64.

58. Cao B, Zheng B, Jankowski RJ, et al. Muscle stem cells differentiate into haematopoietic lineages but retain myogenic potential. Nat Cell Biol. 2003;5(7):640-646.

59. Zuk PA, Zhu M, Ashjian P, et al. Human adipose tissue is a source of multipotent stem cells. Mol Biol Cell. 2002;13(12):4279-4295.

60. Sakaguchi Y, Sekiya I, Yagishita K, Ichinose S, Shinomiya K, Muneta T. Suspended cells from trabecular bone by collagenase digestion become virtually identical to mesenchymal stem cells obtained from marrow aspirates. Blood. 2004;104(9):2728-2735.

61. Lee OK, Kuo TK, Chen WM, Lee KD, Hsieh SL, Chen TH. Isolation of multipotent mesenchymal stem cells from umbilical cord blood. Blood. 2004;103(5):1669-1675.

62. Wakitani S, Mitsuoka T, Nakamura N, Toritsuka Y, Nakamura Y, Horibe $\mathrm{S}$. Autologous bone marrow stromal cell transplantation for repair of full-thickness articular cartilage defects in human patellae: two case reports. Cell Transplant. 2004;13(5):595-600.

63. Wakitani S, Nawata M, Tensho K, Okabe T, Machida H, Ohgushi H. Repair of articular cartilage defects in the patello-femoral joint with autologous bone marrow mesenchymal cell transplantation: three case reports involving nine defects in five knees. J Tissue Eng Regen Med. 2007;1(1):74-79.

64. Wakitani S, Imoto K, Yamamoto T, Saito M, Murata N, Yoneda M. Human autologous culture expanded bone marrow mesenchymal cell transplantation for repair of cartilage defects in osteoarthritic knees. Osteoarthritis Cartilage. 2002;10(3):199-206.

65. Kuroda R, Ishida K, Matsumoto T, et al. Treatment of a full-thickness articular cartilage defect in the femoral condyle of an athlete with autologous bone-marrow stromal cells. Osteoarthritis Cartilage. 2007;15(2):226-231.
66. Wakitani S, Goto T, Pineda SJ, et al. Mesenchymal cell-based repair of large, full-thickness defects of articular cartilage. J Bone Joint Surg Am. 1994;76(4):579-592.

67. Wakitani S, Kawaguchi A, Tokuhara Y, Takaoka K. Present status of and future direction for articular cartilage repair. J Bone Miner Metab. 2008;26(2):115-122.

68. Shino K, Nakagawa S, Inoue M, Horibe S, Yoneda M. Deterioration of patellofemoral articular surfaces after anterior cruciate ligament reconstruction. Am J Sports Med. 1993;21(2):206-211.

69. Segawa Y, Muneta T, Makino H, et al. Mesenchymal stem cells derived from synovium, meniscus, anterior cruciate ligament, and articular chondrocytes share similar gene expression profiles. J Orthop Res. 2009;27(4):435-441.

70. Yoshimura H, Muneta T, Nimura A Yokoyama A, Koga H, Sekiya I. Comparison of rat mesenchymal stem cells derived from bone marrow, synovium, periosteum, adipose tissue, and muscle. Cell Tissue Res. 2007;327(3):449-462.

71. Zhang S, Muneta T, Morito T, Mochizuki T, Sekiya I. Autologous synovial fluid enhances migration of mesenchymal stem cells from synovium of osteoarthritis patients in tissue culture system. J Orthop Res. 2008;26(10):1413-1418.

72. Sakaguchi Y, Sekiya I, Yagishita K, Muneta T. Comparison of human stem cells derived from various mesenchymal tissues: superiority of synovium as a cell source. Arthritis Rheum. 2005;52(8):2521-2529.

73. Koga H, Muneta T, Nagase T, et al. Comparison of mesenchymal tissues-derived stem cells for in vivo chondrogenesis: suitable conditions for cell therapy of cartilage defects in rabbit. Cell Tissue Res. 2008;333(2):207-215.

74. Koga H, Shimaya M, Muneta T, et al. Local adherent technique for transplanting mesenchymal stem cells as a potential treatment of cartilage defect. Arthritis Res Ther. 2008:10(4):R84.

75. Sekiya I, Muneta T, Koga H, et al. [Articular cartilage regeneration with synovial mesenchymal stem cells]. Clin Calcium. 2011;21(6):879-889. Japanese.

76. Ando W, Tateishi K, Hart DA, et al. Cartilage repair using an in vitro generated scaffold-free tissue-engineered construct derived from porcine synovial mesenchymal stem cells. Biomaterials. 2007;28(36): $5462-5470$.

77. Shimomura K, Ando W, Tateishi K, et al. The influence of skeletal maturity on allogenic synovial mesenchymal stem cell-based repair of cartilage in a large animal model. Biomaterials. 2010;31(31): 8004-8011.

78. Shimomura K, Moriguchi Y, Ando W, et al. Osteochondral repair using a scaffold-free tissue-engineered construct derived from synovial mesenchymal stem cells and a hydroxyapatite-based artificial bone. Tissue Eng Part A. 2014;20(17-18):2291-2304.

79. Nakamura T, Sekiya I, Muneta T, et al. Arthroscopic, histological and MRI analyses of cartilage repair after a minimally invasive method of transplantation of allogeneic synovial mesenchymal stromal cells into cartilage defects in pigs. Cytotherapy. 2012;14(3):327-338.

80. Kobayashi T, Watanabe H, Yanagawa T, et al. Motility and growth of human bone-marrow mesenchymal stem cells during ex vivo expansion in autologous serum. J Bone Joint Surg Br. 2005;87(10):1426-1433.

81. Mizuno N, Shiba H, Ozeki Y, et al. Human autologous serum obtained using a completely closed bag system as a substitute for fetal calf serum in human mesenchymal stem cell cultures. Cell Biol Int. 2006;30(6): 521-524.

82. Nimura A, Muneta T, Koga H, et al. Increased proliferation of human synovial mesenchymal stem cells with autologous human serum: comparisons with bone marrow mesenchymal stem cells and with fetal bovine serum. Arthritis Rheum. 2008;58(2):501-510.

83. Hara A, Sato D, Sahara Y. New govermental regulatory system for stem cell-based therapies in Japan. Ther Innov Regul Sci. 2014;48:681-688. 
Orthopedic Research and Reviews

Dovepress

\section{Publish your work in this journal}

Orthopedic Research and Reviews is an international, peer-reviewed, open access journal focusing on the patho-physiology of the musculoskeletal system, trauma, surgery and other corrective interventions to restore mobility and function. Advances in new technologies, materials, techniques and pharmacological agents are particularly welcome. The journal welcomes

original research, clinical studies, reviews \& evaluations, expert opinion and commentary, case reports and extended reports. The manuscript management system is completely online and includes a very quick and fair peer-review system, which is all easy to use. Visit http://www.dovepress. com/testimonials.php to read real quotes from published authors.

Submit your manuscript here: http://www.dovepress.com/orthopedic-research-and-reviews-journal 